Page $\mathbf{1}$ of $\mathbf{2 6}$

\title{
Continuous baseload renewable power using chemical refrigeration
}

\section{cycles}

\author{
Easa I. Al-musleh ${ }^{\mathrm{a}}$, Dharik S. Mallapragada ${ }^{\mathrm{a}}$, and Rakesh Agrawal ${ }^{\mathrm{a}, \mathrm{b}}$ \\ ${ }^{a}$ School of Chemical Engineering, \\ Purdue University, West Lafayette, IN-47907
}

${ }^{\mathrm{b}}$ To whom correspondence should be addressed. Email: agrawalr@purdue.edu 


\begin{abstract}
We propose a cycle to store and supply GWh of electricity from intermittent renewable energy by transforming carbon atoms between carbon dioxide and methane. Among hydrocarbons, methane is associated with the highest energy content per mole of carbon. Therefore, for a given electricity supply, it requires the least amount of carbon circulation. To minimize storage volumes, both carbon dioxide and methane are stored as liquids. When renewable energy is available, methane is synthesized from vaporizing carbon dioxide, and subsequently purified, liquefied and stored. When renewable energy is unavailable, liquid methane is vaporized and oxidized for electricity supply. The produced carbon dioxide is purified and liquefied for storage and subsequent usage. In each case, the electricity required for purification and liquefaction is minimized by integrating the vaporization and liquefaction steps of carbon dioxide and methane. The cycle can achieve $\sim 55 \%$ storage efficiency with much reduced storage volumes compared to other options.
\end{abstract}




\section{Introduction}

Global warming as well as diminishing fossil fuel concerns have motivated the need to supply part or all of the human energy needs from renewable energy sources like solar, wind, and/or tidal waves. However, such energy sources are intermittent in their availability. Thus, their use needs to be coupled with an energy storage system. The implementation of commonly suggested storage systems, such as batteries, hydrogen, and compressed air, at the GWh level of electrical energy storage could potentially be limited because of one or more of the following factors: 1) low volumetric energy density, 2) low storage efficiency (ratio of recovered electricity to stored electricity), and 3) requirements of suitable geological locations (e.g. compressed air storage) (Ibrahim et al., 2008).

In addition to the available infrastructure and technologies for their utilization, carbon fuels, such as methane and methanol, are dense energy carriers which makes them attractive candidates for energy storage. However, synthesizing these carbon fuels in a carbon neutral manner require renewable carbon sources such as biomass and/or atmospheric carbon dioxide (Agrawal et al., 2007; Graves et al., 2011; RihkoStruckmann et al., 2010; Mallapragada et al. 2013). The use of renewable carbon for energy storage in an open loop system (i.e. carbon is vented to the atmosphere) faces the following issues: 1) energy intensive processes for re-capturing carbon dioxide from the atmosphere (or even from industrial exhausts) (Pearson et al., 2012) and 2) availability of land area and other environmental issues associated with the use of biomass.

To overcome the above mentioned challenges, we have previously proposed a closed loop carbon circulation system based on using different carbon-based molecules (Al-musleh et al., 2014a). In case the carbon molecule is methane, the proposed cycle, 
referred as the Methane-Cycle, is shown in Figure 1 using solar energy and other renewable energy sources (Al-musleh et al, 2013). The system is a closed cycle to store and deliver renewable-derived electricity by transforming carbon atoms back and forth between liquid carbon dioxide and liquid methane. This cyclic transformation preserves the carbon atoms, thereby eliminating the need for an external carbon source to synthesize methane. Another feature of the concept is the liquefaction of the carbon dioxide and methane to minimize the volume and eliminate the difficulties associated with high-pressure storage of large quantity of gases. The suitability of other carbonbased molecules has also been investigated for the proposed cycle concept, of which methanol (Al-musleh et al, 2013) and dimethyl ether (Gencer et al., 2014) are identified as favourable alternatives. In this paper we present the details of the steady simulation of the proposed Methane-cycle, with a particular emphasis on the storage mode operation, where renewable energy is stored as liquid methane. The process overview, key simulation results, and thermodynamic analysis are discussed in the following sections.

\section{Methane-Cycle}

Two operation modes are involved in the Methane-Cycle: a storage mode (Figure 1a) corresponding to the period when the dominant renewable energy source, solar, is available and a delivery mode, corresponding to when solar energy is unavailable (Figure $1 \mathrm{~b})$. Referring to Figure 1a, during the storage mode, solar energy along with other renewable energy sources (e.g. wind, tidal etc.) supply grid electricity and provide the required heat and electricity for hydrogen generation using water dissociation (located in the hydrogen generation and heat recovery block). The produced hydrogen is then reacted with gaseous carbon dioxide according to the Sabatier reaction (Brooks et al., 2007), 
generating a gaseous mixture rich in methane and water. After dehydrating the gas stream using compression and molecular sieve adsorbers, the gaseous methane-rich stream is purified and liquefied to be stored at a cryogenic temperature of $-172{ }^{\circ} \mathrm{C}$ and pressure close to atmospheric pressure. Methane purification and liquefaction is carried out using a refrigeration cycle combined with the vaporizing liquid carbon dioxide (produced and stored during the delivery mode).

During the delivery mode (Figure 1b), stored liquid methane is vaporized and then steam reformed to generate synthesis gas rich in hydrogen and carbon monoxide. The synthesis gas is then oxidized electrochemically in a solid oxide fuel cell (SOFC) to generate electricity (Rostrup-Nielsen \& Aasberg-Petersen, 2003). Steam reforming is carried out internally in the SOFC, which is located in the power generation block in Figure $1 \mathrm{~b}$. The waste heat dissipated by the SOFC is absorbed by the endothermic steam reforming reaction as well as by the air fed on the cathode side. The carbon dioxide, water, and unconverted synthesis gas mixture leaving the SOFC is dehydrated (similar to methane dehydration) and the carbon dioxide is purified and liquefied to be stored at -46 ${ }^{\circ} \mathrm{C}$ and 10 bar. The unconverted synthesis gas (around 66 mole $\%$ hydrogen, 23 mole $\%$ carbon monoxide, and 11 mole \% carbon dioxide) is recycled back to the SOFC in the power generation block. Carbon dioxide purification and liquefaction is achieved by making use of the refrigeration available from vaporizing liquid methane. Although not necessary, the water produced during this process is also stored for reuse during the energy storage mode.

The proposed storage cycle is designed for supplying baseload electrical power as part of a future grid that consumes little or no fossil fuels. Thus, even during the storage 
mode, solar energy and the other available renewable energy source(s) should be harnessed in a manner that enables relatively constant power supply, both to the grid as well as the energy storage systems (e.g. storage mode of proposed cycle of Figure 1). According to the literature (Budischak et al., 2013, Jacobson et al., 2011, Sahin, 2000), two options exist to achieve relatively consistent power output for a certain time period using intermittent renewable energy sources. 1) Source electric power from a large geographic regions that takes advantage of differing weather patterns - for example, according to Budischak et al. (2013), wind energy sourced over at least 1,000 km region leads to more consistent power output than the power output from nearby locations. 2) Harness electric power from a diverse range of sources such as wind, solar, and tidal, which can help to stabilize the power output (Budischak et al., 2013). For example, Sahin (2000) analyzes real time solar and wind power data for the Arabian Peninsula, and concludes that relatively constant power output is possible by judiciously combining solar and wind power generation. Additionally, access to geothermal and tidal energy sources, that produce relatively constant electrical power, can contribute to stabilizing the electrical power output (Jacobson et al., 2011). Overall, such strategies can be used to achieve relative constant power supply during the storage mode of the cycle, thereby enabling near steady state operation. Of course, sourcing electrical power from a diversity of renewable energy sources that may or may not be geographically close to each other requires upgrading the existing transmission infrastructure. For close to $100 \%$ renewable energy-based grid, however, upgrading the transmission infrastructure is an unavoidable investment, due to the low energy density of renewable energy sources compared to fossil fuels (Mileva et al., 2013). 
The essential features of the cycle are the following. 1) Although other carbon fuels may be utilized, methane is associated with the highest energy content per mole carbon. Hence, its use minimizes the carbon circulation between the storage and delivery modes for a given power supply (Al-musleh et al., 2014a). 2) Methane and carbon dioxide vaporization and purification/liquefaction steps are integrated. In other words, during the energy storage mode, the refrigeration of vaporizing liquid carbon dioxide is synergistically used in the methane purification and liquefaction step. Therefore, the energy penalty of methane purification and liquefaction is reduced. On the other hand, during the delivery mode the refrigeration available from vaporizing liquid methane along with some compression power for carbon dioxide containing streams is used for carbon dioxide purification and liquefaction. Almost $98 \%$ of the generated carbon dioxide is recovered as liquid with a purity of 99.9 mole \%.

\section{Design and simulation of the cycle}

The detailed process configuration of the storage mode of the proposed cycle (Figure 1a) is shown in Figures 2 and 3. The delivery mode process simulation and its essential characteristics are discussed in detailed elsewhere in the context of electrical power generation from liquefied natural gas (Al-musleh et al., 2014b). Nonetheless, a brief summary of the delivery mode operation is discussed in a later section before the

conclusions. All simulations are carried out with Aspen Plus ${ }^{\mathrm{TM}}$ using the PSRK thermodynamic model and steam tables (AspenTech, 2006; Horstmann et al., 2005). The cycle is simulated for $140 \mathrm{MW}$ of steady electrical power output during the delivery mode, with solar energy assumed to be available for one-fifth of a twenty-four hour day. In other words, in a twenty-four hour day, the cycle operates in storage mode for 4.8 
hours and delivery mode for 19.2 hours that is representative of solar energy availability in the midwestern and central United States (Agrawal et al., 2007). Detailed simulation basis and material/energy balance are available in Table 3 and the supplementary information (SI), respectively.

3.1. Hydrogen generation and heat recovery

\subsubsection{Hydrogen generation}

Due to its high efficiency, steam electrolysis using solid oxide electrolysis cells (SOEC) was the preferred method for hydrogen generation (Graves et al., 2011). The SOEC also has the potential to operate as a SOFC during the delivery mode of the cycle, which enables capital cost savings and avoids daily thermal cycling of the device (O'Brien, 2008). In our simulation, the model for the SOEC heat and power consumption calculations is based on the work of Udagawa et al. (2007) and Jan Van herle et al. (2003 and 2014) and was implemented in Aspen Plus ${ }^{\mathrm{TM}}$ using Aspen Calculator tool (AspenTech, 2006). In the model, the electrochemical losses due to experimental based anode/cathode activation polarization, cathode diffusion polarization, electrolyte resistance, and interconnect resistance are considered. Electrochemical losses arising from anode diffusion polarization are neglected (Udagawa et al., 2007). Even with relatively constant power input available during the storage mode (using the aforementioned strategies), there are likely to exist small variations in power input to the SOEC that have not been considered here. A dynamic simulation of the storage mode, that incorporates the experimental observations of the dynamic operation of SOEC (Petipas et al., 2013) is required to consider the impact of small variations of renewable power input. Such a dynamic simulation, however, is outside the scope of this work. 
Referring to Figure 2, SOEC feed water (sourced from the water storage tank) is pumped via pump P-1 to a pressure of 12 bar. The pressurized water is then converted to superheated steam at $\sim 250{ }^{\circ} \mathrm{C}$ in heat exchanger E-1 and the exothermic reaction heat from the reactors $\mathrm{R}-2$ and $\mathrm{R}-1$. To maintain 10 mole $\%$ hydrogen content at the inlet of the SOEC cathode (i.e stream 8$)$, saturated steam ( 11 bar) leaving steam drum V-1, prior to superheating, is mixed with recycle hydrogen from compressor K-2 (stream 54). The presence of hydrogen in the feed to the SOEC cathode is essential to slow down the oxidation and degradation of the nickel cermet electrodes (of the SOEC) when exposed to high steam concentrations (O'Brien, 2008; Yildiz et al., 2005). The superheated steamhydrogen mixture, stream 5, is further heated in heat exchangers E-2, E-3, and E-4 to the operating temperature of the SOEC, equal to $950^{\circ} \mathrm{C}$. This is close to the maximum operating temperature limit of $1,000{ }^{\circ} \mathrm{C}^{1}$ for existing SOFC systems (EG\&G TechnicalServices, 2004). As shown in Figure 2, heat exchanger E-4 uses concentrated high temperature solar heat, which is assumed in this work to be available at $978{ }^{\circ} \mathrm{C}$.

At the SOEC cathode, steam is dissociated into gaseous hydrogen and oxygen ions (see Eq. 1). Depending on the steam conversion (i.e. SOEC operating current), the energy balance of the SOEC can be met using either electrical power input or electrical power and heat input (see SI and (O'Brien, 2008)). To achieve high process efficiency and simplify the heat management of the cycle, the SOEC is operated at the thermoneutral condition (steam conversion of around 98\%) where the device only requires

\footnotetext{
${ }^{1}$ SOFC and SOEC operation are assumed to be carried out by a single device. Hence, maximum temperature of the SOEC is assumed to be the same as the maximum temperature of the SOFC.
} 
electrical power input. Here, the heat dissipation of the cell exactly provides the necessary heat for the enthalpy change around the SOEC.

$$
\text { Cathode: } \mathrm{H}_{2} \mathrm{O}(\mathrm{g})+2 \mathrm{e}^{-} \longrightarrow \mathrm{H}_{2}(\mathrm{~g})+\mathrm{O}^{2-}
$$

The generated oxygen ions diffuse through the yttria-stabilised zirconia electrolyte to the anode where they combine to form molecular oxygen and electrons according to Eq. 2. The generated oxygen at the anode is mixed with sweep air, fed via multistage intercooled compressor K-1 for oxygen dilution. The air flow is specified to maintain 50 mole \% oxygen content in stream 59, which reduces the anode material degradation from exposure to high temperature, high purity oxygen (McKellar et al., 2007; O'Brien, 2008). The air feed, stream 56, is heated to $950{ }^{\circ} \mathrm{C}$ via heat exchange with stream 59 (in E-16) followed by additional heating in E-17 using solar heat available at $978{ }^{\circ} \mathrm{C}$. Before it is discharged into the atmosphere, the enriched air, stream 61 , is expanded in turbine $\mathrm{T}-1$ to generate additional electrical power.

Anode: $\mathrm{O}^{2-} \longrightarrow 2 \mathrm{e}^{-}+0.5 \mathrm{O}_{2}(\mathrm{~g})$

\subsubsection{Heat recovery}

The hydrogen-rich mixture (stream 10) leaving heat exchanger E-3 at 9.5 bar and $489{ }^{\circ} \mathrm{C}$ is utilized as a heat source for power generation via a Rankine cycle. The cycle consists of a heat recovery steam generator (HRSG) that generates high pressure (stream $\mathrm{H}$ at $\sim 120$ bar and $460^{\circ} \mathrm{C}$ ), medium pressure (stream $\mathrm{E}$ at $\sim 30$ bar and $320^{\circ} \mathrm{C}$ ), and low pressure (stream B at $\sim 5$ bar and $230^{\circ} \mathrm{C}$ ) superheated steam. Power is generated via the steam turbines T-2, T-3, and T-4 operating at discharge pressures of 30, 5, and 0.07 bar, respectively. The discharged steam from turbine T-2 (i.e. stream I) is reheated to a temperature of $460{ }^{\circ} \mathrm{C}$ in the HRSG prior to its expansion in turbine T-3. Sensitivity 
analyses showing the impact of the cycle operating conditions on the electrical power output is presented in the SI.

\subsection{Methane generation (Sabatier reaction)}

Methane generation via the exothermic Sabatier reaction of Eq. 3 is favored at higher than ambient pressure and low temperature $\left(\sim 350^{\circ} \mathrm{C}\right)$ operation. Experimental studies revel that the actual carbon dioxide conversion approaches equilibrium for temperatures greater than $300{ }^{\circ} \mathrm{C}$ with formation of carbon monoxide as a byproduct (Brooks et al., 2007; Lunde, 1974; Lunde \& Kester, 1973). In the process of Figure 2, methane generation is carried out at $\sim 22$ bar in a high temperature sabatier reactor $(\mathrm{R}-1)$ followed a low temperature Sabatier reactor (R-2) reactor with intermediate byproduct water separation (see SI for pressure effect on conversion). This approach allows for achieving $\sim 100$ mole $\%$ per pass carbon dioxide conversion to methane. $\mathrm{R}-1$ at $400^{\circ} \mathrm{C}$, and R-2 at $350^{\circ} \mathrm{C}$, were simulated using an equilibrium approach, while accounting for carbon monoxide formation via water-gas shift reaction (Eq. 4).

$$
\begin{aligned}
& \mathrm{CO}_{2}+4 \mathrm{H}_{2} \longleftrightarrow \mathrm{CH}_{4}+2 \mathrm{H}_{2} \mathrm{O} \\
& \mathrm{CO}+\mathrm{H}_{2} \mathrm{O} \longleftrightarrow \mathrm{CO}_{2}+\mathrm{H}_{2}
\end{aligned}
$$

Referring to Figure 2, the hydrogen-rich steam mixture leaving the HRSG via stream 11 is cooled to $43{ }^{\circ} \mathrm{C}$ using cooling water in heat exchanger E-5. The uncondensed hydrogen and water from vapor-liquid separator ( 99 mole \%), stream 13, is split as streams 14 and 52. While stream 52 is recycled to the SOEC via compressor K2 (see section 3.1.1), stream 14 is compressed via compressor K-3 to produce stream 15 at 22 bar. This stream is then mixed with stream 41a, which is sourced from mixing 99.9 mole $\%$ carbon dioxide (i.e. stream 67) and the recycle streams 40 and 47 . The mixed 
stream is then heated in heat exchanger E- 6 to $\sim 340{ }^{\circ} \mathrm{C}$ to be fed to reactor R-1 with a per pass carbon conversion of $96.2 \%$. Stream 17 leaving R-1 is cooled to a temperature of 43 ${ }^{\circ} \mathrm{C}$ in the downstream heat exchangers (i.e. E-6, E-1, E-7, E-8, and E-9) for heat recovery and byproduct water condensation. The condensed water is separated in vapor-liquid separator V-2 for further processing in the compression and dehydration part of the process (see section 3.3). Stream 23 leaving V-2 is heated to $300^{\circ} \mathrm{C}$ in heat exchanger E-6 and fed to R-2 reactor, which has per pass carbon conversion of 99.4 mole\%. Similar to stream 17, stream 25 leaving R-2 is cooled to $43{ }^{\circ} \mathrm{C}$ in the downstream heat exchangers (i.e. E-6, E-10, and E-11) for heat recovery and byproduct water condensation. Stream 28 , containing $89 \%$ methane, $7 \%$ water, and $4 \%$ hydrogen (on a mole basis), is sent to the compression and dehydration part of the process.

\subsection{Compression and dehydration}

Prior to its purification and liquefaction, methane needs to be dehydrated to the extent that the water dew point is lower than methane storage temperature (i.e. $-172{ }^{\circ} \mathrm{C}$ ). This is necessary to avoid water freezing conditions during purification and liquefaction in the cryogenic heat exchangers E-14 and E-15 (in Figure 3). For the same reason of freezing, the unconverted carbon dioxide accompanying methane in stream 28 needs to be completely removed prior to E-14 and E-15. The removal of water and carbon dioxide are best achieved using 4A molecular sieve adsorbers (Campbell, 2001; Maddox \& Morgan, 1998). As identified using the flowsheet optimization elaborated in Table 1, the energy efficiency of the process is improved by pressurizing the methane-containing stream (i.e. stream 28) prior to the adsorption step. In general, compression followed by 
cooling to near ambient temperature causes further water condensation which reduces the regeneration heat duty on the molecular sieve adsorbers (Al-musleh et al., 2014b).

In Figure 2, stream 28 ( 89 mole \% methane) is fed to vapor-liquid separator V-3 to remove the condensed water. Vapor stream 29 leaving V-3 is compressed to $\sim 50$ bar in K-4 (identified using the optimization approach of Table 1). Stream 30 is mixed with stream R6 (described below) and then cooled in heat exchanger E-13 to $43{ }^{\circ} \mathrm{C}$ for further water condensation. The condensed water is separated in vapor-liquid separator V-4, pressure reduced to $\sim 19$ bar (stream 43 pressure), and then fed to separator V-3. In separator V-3, any dissolved gases (i.e. hydrogen, methane, and carbon dioxide) are separated for recycle via compressor K-4. On the other hand, the vapor leaving vaporliquid separator V-4 (stream 32) is routed to molecular sieve adsorber V-5 to remove the residual water and unconverted carbon dioxide $(\sim 0.35$ mole $\%$ water and 0.02 mole $\%$ carbon dioxide). When the adsorber becomes saturated with water and carbon dioxide, it goes through a regeneration cycle where the water and carbon dioxide are removed by using heat. In this work, adsorber V-5 is designed to be regenerated during the delivery mode of the cycle (Al-musleh et al., 2014b).

Stream 33, leaving V-5 ( 96 mole \% methane) is split into streams 34 and R1. While stream 34 is sent to the methane purification and liquefaction block (see section 3.4), stream R1 is heated in heat exchanger E- 6 to a temperature of $310{ }^{\circ} \mathrm{C}$ to be used as a heat source for regenerating the molecular sieve adsorbers used for carbon dioxide dehydration in the delivery (Al-musleh et al., 2014b). Stream R3, containing the desorbed water, at $290{ }^{\circ} \mathrm{C}$ is cooled in heat exchangers E-6 and E-12 to a temperature of $43{ }^{\circ} \mathrm{C}$ which condenses the water removed from the delivery mode adsorbers. The condensed 
water is separated in vapor-liquid separator V-7 and pressure reduced to 19 bar to release a portion of the dissolved gases. These gases are separated in vapor-liquid separator V-3 and recycled to compressor K-4.

Stream 44 leaving separator V-3, accounting for $\sim 4 \%$ of the water generated in the process, is pressure reduced to 2 bar and mixed with stream 51, the hydrogen-water mixture ( 99.7 mole \% water) from vapor-liquid separator $\mathrm{V}-1$. The mixed stream along with stream 49 is fed to stripper column C-1. Here, the residual dissolved gases are stripped out of the water using stripping steam supplied by the column reboiler E-7. The stripped gases leave the top of column $\mathrm{C}-1$ to be recycled to reactor $\mathrm{R}-1$ via recycle compressor K-8 (stream 47) followed by recycle multistage intercooled compressor K-6 (stream 41).

\subsection{Methane purification and liquefaction}

The purification and liquefaction of methane is carried out using a Mixed Refrigerant (MR) vapor compression cycle (Al-musleh, 2010) along with the unique feature of recovering refrigeration from the evaporating liquid carbon dioxide. The MR cycle shown in Figure 3, consists of MR multistage intercooled compressor K-7, cryogenic liquefaction heat exchanger E-14, cryogenic subcooling heat exchanger E-15, and a Joule-Thomson (J-T) expansion valve. The MR, comprising of $9 \%$ nitrogen, $31 \%$ methane, $38 \%$ ethane, and $22 \%$ propane (mole basis), is circulated via compressor $\mathrm{K}-7$ to provide a low temperature heat sink for heat exchangers E-14 and E-15 by its nonisothermal evaporation.

Referring to Figure 3, stream 34 ( $~ 96$ mole\% methane) is cooled and condensed in cryogenic heat exchanger E-14 to $-170{ }^{\circ} \mathrm{C}$. The condensed stream 35 is then pressure 
reduced to almost 2 bar to release the light gases dissolved in the bulk liquid (i.e. hydrogen and carbon monoxide). Vapor-liquid separator V-6 separates these gases to leave via stream 38 ( $\sim 75$ mole $\%$ hydrogen, $\sim 25$ mole $\%$ methane, and $\sim 46$ ppm carbon monoxide) for refrigeration recovery in heat exchanger E-14. The accumulated liquid in separator V-6 is subcooled in heat exchanger E-15 to $-172{ }^{\circ} \mathrm{C}$ and then sent to the liquid methane storage tank.

Stored liquid carbon dioxide ( 99.9 mole $\%$ ) at $-46{ }^{\circ} \mathrm{C}$ is pumped via pump P-3 to a pressure of 23 bar (reactor R-1 pressure plus pressure drops) to be then evaporated in heat exchanger E-14. In E-14, liquid carbon dioxide provides refrigeration from latent and sensible heat to cool streams 34 and stream b (high pressure MR) from $43{ }^{\circ} \mathrm{C}$ to close to $-45{ }^{\circ} \mathrm{C}$. Gaseous carbon dioxide in stream 65 leaves heat exchanger E-14 at $-11{ }^{\circ} \mathrm{C}$, which is further heated to $43^{\circ} \mathrm{C}$ (stream 66) via the interstage cooler of $\mathrm{K}-7$. This heat exchange also helps to reduce the compression power of K-7. On the other hand, low pressure $\mathrm{MR}$ at 1.1 bar and $-11^{\circ} \mathrm{C}$, is compressed via compressor $\mathrm{K}-7$ to 27 bar (stream $\mathrm{f}$ ) for cooling and condensation in the downstream heat exchangers. The condensed high pressure MR leaving heat exchanger E-15 via stream $\mathrm{c}$ at $-173{ }^{\circ} \mathrm{C}$ is pressure reduced (using the J-T valve) to 1.2 bar. This further cools the MR from -173 to $-176{ }^{\circ} \mathrm{C}$. The resulting low pressure MR stream $d$ is sufficient to provide the refrigeration needed by the process (i.e. refrigeration beyond liquid carbon dioxide capabilities) by its nonisothermal evaporation and superheating in heat exchangers E-15 and E-14.

The operating conditions of the process are identified using the optimization problem formulation described in Table 1. Here, the MR compressor power (i.e. K-7 power) is minimized subject to a minimum temperature approach of $1{ }^{\circ} \mathrm{C}$ in heat 
exchangers E-14 and E-15. Aspen Plus ${ }^{\mathrm{TM}}$ Sequential Quadratic Programming (SQP) is used to solve the power minimization problem of Table 1 . To ensure a good quality local solution, the SQP method is solved with different set of initial values for the independent variables.

\subsection{Delivery mode of the proposed cycle}

The delivery mode of the cycle consists of the following four major sections: power generation using SOFC, heat recovery from the SOFC anode exhaust, anode exhaust compression and dehydration, and carbon dioxide capture and liquefaction. The reader is referred to Al-musleh et al. (2014b) for a detailed description of the process flowsheet and simulation results. Unlike previous approaches of utilizing the SOFC unconverted fuel (i.e. carbon monoxide and hydrogen) using combustion based processes (Duan et al., 2013 , Campanari, 2002), the proposed delivery mode process uses a cryogenic based approach to separate (or capture) carbon dioxide from the unconverted fuel which is then recycled to the SOFC. In the carbon dioxide separation process, the main source of refrigeration comes from the methane evaporation step. Here, the free of water SOFC exhaust (containing 32.1\%Hydrogen, 13.5\% carbon monoxide, and $54.5 \%$ carbon dioxide) is cooled using three cooling stages, each operating with pressure of 14.8bar, 33.8bar and 100bar, respectively. The 14.8 bar cooled carbon dioxide stream leaves the first cooling stage to be fed to a first rectifying column at $-2.6{ }^{\circ} \mathrm{C}$ after reducing its pressure to near 10 bar. A reflux stream (at a temperature of $-41.5^{\circ} \mathrm{C}$ ) is utilized in the column to separate and condense the carbon dioxide. The vapor stream leaving the column, containing unrecovered carbon dioxide, is compressed to 33.8 bar for cooling in the second cooling stage. This stream is fed to a second rectifying column (at a 
temperature of $0.6{ }^{\circ} \mathrm{C}$ ) that utilizes a reflux stream (at $-52.9{ }^{\circ} \mathrm{C}$ ) from the third cooling stage. The liquid leaving the second column is reduced in pressure and utilized as a reflux for the first column. On the other hand, the vapor leaving the second column is compressed to 100 bar then partially condensed in the third cooling stage (temperature of near $\left.-52.7^{\circ} \mathrm{C}\right)$. The condensed carbon dioxide from the third stage is separated using a vapor-liquid separator to be utilized as a reflux stream in the second rectifying column after reducing its pressure to near 33.8 bar. The vapor leaving the vapor-liquid separator (which contains near 12 mole\% carbon dioxide) is recycled to the anode side of the SOFC. This recycle stream is estimated to increase the power output of the SOFC by near $22 \%$ when compared to SOFC operation using vaporizing methane alone.

Prior to the carbon dioxide capture and liquefaction process (and after the heat recovery section), the SOFC anode exhaust is compressed to a pressure of 14.8 bar and then dehydrated using molecular sieve adsorbers (Campbell, 2001). As mentioned above dehydration is essential to avoid freezing the water in the down steam cryogenic heat exchangers. Optimization of the key process parameters (in a manner similar to the one shown in Table 1) reveals that the compression of the SOFC anode exhaust from near 10 bar (i.e. SOFC operating pressure) to 14.8 bar leads to the maximum power generation efficiency of the delivery mode at $\sim 71 \%$ on a lower heating value (LHV) basis, with $\sim 100 \%$ carbon dioxide capture.

\section{Results and discussion}

\subsection{Overall performance}


Table 2 summarizes the performance of the Methane-Cycle as derived from the rigorous simulation. The storage mode energy efficiency, defined as the ratio of the LHV of stored methane to the net electrical power input to the process, is $\sim 77.3 \%$. Here, net power includes the electrical power supplied as well as the exergy (or work potential) of the external (solar) heat utilized in heat exchangers E-4 and E-17, shown in Figure 2. Similarly, the energy efficiency of the delivery mode of the cycle, defined as the ratio of net power output to LHV of stored methane, is estimated from rigorous simulations to be $71 \%$ (Al-musleh et al., 2014b). This results in an overall storage efficiency, defined as ratio of net electrical energy output in delivery mode to electrical energy input in storage mode, of $\sim 54.9 \%$. For the storage mode, the SOEC consumes the highest fraction of the gross power input at $91.7 \%$, followed by air compressor K-1 ( $3.0 \%)$, the exergy input of the heat supplied to the heat exchangers E-4 and E-17 ( 2\%), compressor K-3 ( $1.5 \%)$, and MR compressor K-7 ( $1.3 \%)$. On the other hand, the total power generated from the turbines (i.e. T-1, T-2, T-3, and T-4) of $49 \mathrm{MW}$ is the difference between the gross power and net power input, and accounts for $\sim 72 \%$ of the power required by the compressors.

If the SOEC pressure is increased, beyond the current maximum pressure rating of 10 bar (Lundberg et al., 2000), to 24 bar (i.e. reactors pressure plus pressure drops), then compressor K-3 can be eliminated. The net result is an increase in storage mode efficiency from 77.3 to $78.3 \%$, which improves the overall storage efficiency from $54.9 \%$ to $55.6 \%$. Although further increasing the SOEC operating pressure (where R-1 and R-2 pressure also increase) reduces the work of compressor K-4, it will come at the expense of evaporating liquid carbon dioxide at higher temperatures and higher pressures 
(or lower latent heats). For example, a SOEC operating pressure of 57 bar (i.e. stream 16 pressure plus pressure drops) will eliminate the need for compressors K-3 and K-4. However, liquid carbon dioxide evaporation temperature will increase from $-16^{\circ} \mathrm{C}$ (at 27 bar) to $17{ }^{\circ} \mathrm{C}$ (at 56 bar). Simultaneously, the rate of latent heat of evaporation available will decrease from $\sim 12$ to $\sim 7 \mathrm{MW}$. These two effects increase the work of compressor K7 by $\sim 5.5 \%$ compared to the base case and 24 bar case mentioned above. The overall effect is only a small increase in the storage mode efficiency from $78.3 \%$ to $\sim 78.7 \%$ as SOEC operating pressure is increased from 24 to 57 bar.

For the same electrical energy output, the Methane-Cycle total storage volume (sum of liquid methane and carbon dioxide volumes) is estimated to be more than 7 and 252 times less than the storage volumes of sodium sulfur battery and compressed air storage systems, respectively (Al-musleh et al., 2014a). While the volume of liquid hydrogen is comparable to the total storage volume of the Methane-Cycle for the same electrical energy output, the Methane-Cycle storage efficiency is higher than the liquid hydrogen storage efficiency of $\sim 33 \%$ (Al-musleh et al., 2014a).

4.2 Thermodynamic analysis

As revealed by the process composite curves of the storage mode of the MethaneCycle in Figure 4a, around $124 \mathrm{MW}$ of heat (with a maximum temperature of $172{ }^{\circ} \mathrm{C}$ ) is rejected by the process. This is equivalent to around $41 \mathrm{MW}$ of exergy, a portion of which could have been partially recovered using an organic Rankine cycle (Bourji \& Winstead, 2013). Assuming that a Rankine cycle is capable of recovering $50 \%$ of the exergy available from the wasted heat at $172^{\circ} \mathrm{C}$ as electricity, the storage mode energy 
efficiency can be then estimated to increase from 77.3 to $78.8 \%$. The overall effect is a possible increase in the overall storage efficiency from 54.9 to $56 \%$.

The minimum work of methane purification and liquefaction, $W_{M i n}^{\text {Methane }}$, calculated using the exergy balance of Eq. 5, is estimated to be 8.8 MW. Similarly, Eq. 6 estimates the maximum work available from vaporizing liquid carbon dioxide, $W_{\text {Max. }}^{\text {Carbon dioxide }}$, to be 3.1 MW. Here, $E X_{j}$ is the exergy associated with stream $j$, which are listed in the SI.

$$
\begin{aligned}
& W_{\text {Min. }}^{\text {Methane }}=E X_{39}+E X_{37}-E X_{34} \\
& W_{\text {Max. }}^{\text {Carbon dioxide }}=E X_{63}-E X_{66}
\end{aligned}
$$

If liquid carbon dioxide is utilized to power a reversible refrigeration cycle for methane purification and liquefaction, then the refrigeration cycle will require an additional 5.7 MW of reversible power. In the actual process, the electrical power input is almost 2.5 times the reversible power input (i.e. $14 \mathrm{MW}$ ), a consequence of the different parasitic losses associated with the process, most importantly the temperature differences associated with the heat exchange process. Minimizing the power consumption of methane purification and liquefaction process requires minimizing the temperature differences across heat exchangers E-14 and E-15 (Al-musleh, 2010). As seen from the composite curves for E-14 and E-15 in Figure 4b, the designed purification and liquefaction process is capable of maintaining a temperature difference of around $1{ }^{\circ} \mathrm{C}$ across most of the heat exchangers length. The largest temperature differences are encountered in the warmest section, where the hot streams (i.e. stream 34 and stream b) are cooled from 43 to $-25^{\circ} \mathrm{C}$. This is a consequence of the latent heat of vaporization of liquid carbon dioxide, available at a constant temperature of $-16^{\circ} \mathrm{C}$. The process simulation also showed that the MR compressor K-7 power would increase from 14 to 21 
MW if the refrigeration of liquid carbon dioxide is not utilized and the entire process (i.e. methane purification and liquefaction) refrigeration is provided by the MR cycle alone.

\section{Methane-Cycle with gas storage}

Compressed methane is also investigated as an alternative method of storage for the Methane-Cycle. The flowsheet is similar to Figure 2 with the following exceptions. 1) Methane purification and liquefaction (storage mode) is replaced with the compression and storage process shown in Figure 5. Here, rather than purifying the methane-rich stream (stream 34) leaving the molecular sieve adsorber, it is compressed to 205 bar in multistage compressor K-7. Since compression work is reduced at lower temperatures, stream 34 is cooled to subambient temperature of $-45{ }^{\circ} \mathrm{C}$ prior to compression. This is achieved in heat exchanger E-14 using the refrigeration released from the evaporating liquid carbon dioxide. 2) Since the methane-rich stream is not purified from unconverted hydrogen and byproduct carbon monoxide, the process eliminates a recycle stream (stream 40 in the process of Figure 2). 3) Unlike liquid methane, stored gaseous methane has no refrigeration. Therefore, carbon dioxide purification and liquefaction during the delivery mode is achieved entirely using an MR vapor compression refrigeration cycle (Al-musleh et al., 2014b).

In addition to Aspen Plus ${ }^{\mathrm{TM}}$ steady state simulation of the cycle, the process of charging the storage tanks with compressed methane is dynamically simulated, in a stand alone mode, using Aspen Hysys ${ }^{\mathrm{TM}}$ for accurate compression power calculations (see SI). The process simulations show that the methane gas storage volume (at 205 bar and 31 ${ }^{\circ} \mathrm{C}$ ) is higher than methane liquid volume (in the flowsheet of Figure 2) by a factor of 3.6 with a slightly lower overall storage efficiency of $54.4 \%$. The reduction in the overall 
storage efficiency is caused by the need to produce more methane during the storage mode. This additional methane is consumed to supply the electrical power needed for carbon dioxide purification and liquefaction (using MR cycle) during the delivery mode.

\section{Conclusions}

The proposed system can enable GWh level or more electrical energy storage from an intermittently available energy source, with overall storage efficiency near $\sim 55 \%$ and much reduced storage volumes compared to other options. The system is a closed loop cycle in which carbon atoms are transformed between liquid carbon dioxide and liquid methane. The main features of the cycle are: 1) methane has the highest energy content per mole carbon, which minimizes the amount of carbon to be cycled, 2) methane and carbon dioxide are liquefied for storage, thereby eliminating the challenges of high pressure storage of large quantities of gases, and 3) the integration of carbon dioxide and methane vaporization and liquefaction steps minimize the energy penalty associated with the refrigeration requirements.

\section{Acknowledgments}

Research supported by Qatar University, by the Centre for Direct Catalytic Conversion of Biomass to Biofuels, an Energy Frontier Research Centre funded by the U.S. Department of Energy (DOE), Office of Science, Basic Energy Sciences (BES), under Award \# DE-SC0000997, and by the National Science Foundation Solar Economy IGERT (0903670-DGE).

\section{References}

Adams, TA, Barton PI. High-Efficiency Power Production from Coal with Carbon Capture. AIChE J 2010;56:3120-36. 
Agrawal R, Singh NR, Ribeiro FH, Delgass WN. Sustainable fuel for the transportation sector. Proc Natl Acad Sci USA 2007;104:4828-33.

Allam R et al. Capture of CO2. In: B. Metz, O. Davidson HD, Coninck ML, Meyer L, editors. Intergovernmental Panel on Climate Change Special Report on Carbon Dioxide Capture and Storage. New York: Cambridge University Press; 2005.

Allam R, White V, Ivens N, Simmonds M. The Oxyfuel Baseline: Revamping Heaters and Boilers to Oxyfiring by Cryogenic Air Separation and Flue Gas Recycle. In: Thomas DC, editor. Carbon Dioxide Capture for Storage in Deep Geologic Formations-Results from the CO2 Capture Project (Vol. 1). New York: Elsevier;2005.

Al-musleh EI. Efficient liquefaction cycles for natural gas. Unpublished thesis 2010 Purdue Univeristy, IN, USA.

Al-musleh EI, Mallapragada DS, Agrawal R. Continuous power supply from a baseload renewable power plant. Appl Energy 2014a;122:83-93.

Al-musleh EI, Mallapragada DS, Agrawal R. Efficient Electrochemical Refrigeration Power Plant using Natural Gas with 100 \% CO2 capture. Submitted 2014b.

Al-musleh, EI, Mallapragada DS, Agrawal R. GWh Level Renewable Energy Storage and Supply using Liquid CO2. In: Kraslawski A, Turunen I, editors. Proceedings of the $23^{\text {rd }}$ European Symposium on Computer Aided Process Engineering; 2013.p.415-420.

AspenTech. ASPEN Plus users guide. Aspen Technology Inc. 2006.

Bourji A, Winstead A. Optimizing an Organic Rankine Cycle. Chem Eng Progr 2013;109:35-39.

Budischak C, Sewell D, Thomson H, Mach L, Veron DE, Kempton W. Cost-minimized combinations of wind power, solar power and electrochemical storage, powering the grid up to $99.9 \%$ of the time. J Power Sources 2013;225: 60-74.

Brooks KP, Hu J, Zhu H, Kee RJ. Methanation of carbon dioxide by hydrogen reduction using the Sabatier process in microchannel reactors. Chem Eng Sci 2013;62: 1161-70.

Campbell JM. Gas Conditioning and Processing, Vol 2: The Equipment Modules.8th ed. Norman, Oklahoma: John M Campbell and Company; 2001.

Campanari S. Carbon dioxide separation from high temperature fuel cell power plants. J Power Sources 2002;112:273-89.

Duan L, Huang K, Zhang, Yang Y. Comparison study on different SOFC hybrid systems with zero-CO2 emission. Energy 2013;58:66-77.

EG\&G TechnicalServices. Fuel Cell Handbook. Morgantown, West Virginia: US Department of Energy; 2004.

Foglietta JH. Consider dual independent expander refrigeration for LNG production. Hydrocarb Process 2004;83:39-44.

Graves C, Ebbesen SD, Mogensen M, Lackner KS. Sustainable hydrocarbon fuels by recycling $\mathrm{CO} 2$ and $\mathrm{H} 2 \mathrm{O}$ with renewable or nuclear energy. Renew Sustain Energy Rev 2011;15:1-23.

Gencer E, Al-musleh EI, Mallapragada DS, Agrawal R. Uninterrupted Renewable Power through Chemical Storage. Curr Opin Chem Eng 2014;5:29-36. 
Heatric. Features and capabilities of high pressure Printed Circuit Heat Exchangers (PCHEs). http://www.heatric.com/typical_characteristics.html. Accessed on April 2014.

Horstmann S, Fischer K, Gmehling J. Application of PSRK for Process Design. Chem Eng Commun 2005;192:336-50.

Hubbard RA. Gas Conditioning and Processing. 8th ed. Norman, Oklahoma: John M Campbell and Company;2001.

Hydrocarbon Processing. Gas Processes Handbook. Houston, Texas: Gulf publishing Company;2004.

Ibrahim H, Ilinca A, Perron J. Energy storage systems-Characteristics and comparisons. Renew Sustain Energ Rev 2008;12:1221-50.

Jacobson M, Delucchi M. Providing all global energy with wind, water, and solar power, Part I:Technologies, energy resources, quantities and areas of infrastructure, and materials. Energy Policy 2011;39:1154-69.

Lundberg WL et al. Pressurized Solid Oxide Fuel Cell/Gas Turbine Power System. Pittsburgh, PA: Siemens Westinghouse Power Corporation; 2000.

Lunde PJ. Modeling, Simulation, and Operation of a Sabatier Reactor. Ind Eng Chem 1974;13:226-33.

Lunde PJ, Kester FL. Rates of Methane Formation from Carbon Dioxide and Hydrogen Over a Ruthenium Catalyst. J Catal, 1973;30:423-29.

Mileva A, Nelson JH, Johnston J, Kammen DM. Sun Shot Solar Power Reduces Costs and Uncertainty in Future Low-Carbon Electricity Systems. Environ Sci Technol 2013;47:9053-60.

Maddox RN, Morgan DJ. Gas conditioning and processing:Gas treating and sulfur recovery 4th ed. Norman, Oklahoma: Campbell Petroleum Series;1998.

Mallapragada DS, Singh NR, Curteanu V, Agrawal R. Sun-to-Fuel Assessment of Routes for Fixing $\mathrm{CO}_{2}$ as Liquid Fuel. Ind Eng Chem Res 2013;52:5136-44.

McDonald CF. Compact buffer zone plate-fin IHX- the key component for high temperature nuclear process heat realization with advanced MHR. Applied Thermal Eng, 1996;16:3-32.

McKellar MG, O'Brien JE, Harvego EA, Herring, JS. Optimized flow sheet for a reference commercial scale nuclear driven high temperature electrolysis hydrogen production plant. Idaho Falls, Idaho: Idaho National Laboratory; 2007.

O'Brien, JE. Thermodynamic consierations for thermal water splitting processes and high temperature electrolysis. Proceedings of the 2008 International Mechanical Engineering Congress and Exposition; 2008. p.639-651.

Pearson RJ et al. Energy Storage via Carbon-Neutral Fuels Made From $\mathrm{CO}_{2}$, Water, and Renewable Energy. Proc IEEE 2012;100:440-60.

Petipas F, Fu Q, Brisse A, Bouallou C. Transient operation of solid oxide electrolysis cell. Int J Hydrogen Energy 2013;38:2957-64.

Rihko-Struckmann LK, Peschel A, Hanke-Rauschenbach R, Sundmacher K. Assessment of Methanol Synthesis Utilizing Exhaust CO2 for Chemical Storage of Electrical Energy. Ind Eng Chem Res, 2010; 49:11073-78.

Rostrup-Nielsen JR, Aasberg-Petersen K. Steam reforming, ATR, partial oxidation:catalysts and reaction engineering. In: Vielstich W, Gasteiger HA, 
Lamm A, editors. Handbook of Fuel Cells-Fundamentals, Technology and Applications. New York: Wiley;2003. p. 160-176.

Sahin A. Applicability of Wind and Solar Thermal Hybrid Power Systems in the Northeastern Part fo the Arabian Peninsula. Energy sources 2000;22:845-850.

Seider WD, Seader JD, Lewin DR, Widagdo S. Product and Process Design Principles. New York: John Wiley \& Sons Ltd; 2009.

Smith R. Chemical Process Design and Integration. England: Wiley;2005.

Udagawa J, Aguiar P, Brandon NP. Hydrogen production through steam electrolysis: Model-based steady state performance of a cathode-supported intermediate temperature solid oxide electrolysis cell. J Power Sources, 2007;166: 127-36.

Van herle J, Maréchal F, Leuenberger S, Favrat D. Energy balance model of a SOFC cogenerator operated with biogas. J Power Sources 2003;118:375-83.

Van herle J, Maréchal F, Leuenberger S, Membrez Y, Bucheli O, Favrat D. Process flow model of solid oxide fuel cell system supplied with sewage biogas. J Power Sources 2004;131:127-41.

Woodruff EB, Lammers, HB, Lammers, TF. Steam plant operation 9th ed. New York: McGrawHill; 2012.

Yildiz B, Hohnholt KJ, Kazimi, MS. Hydrogen Production using High-Temperature steam electrolysis supported by advanced gas reactors with supercritical CO2 cycles. Nuclear Technol 2005;155:1-21.

\section{Figure legends}

Figure 1. Simplified block diagram of the proposed Methane-Cycle, (a) storage mode,

(b) delivery mode (Al-musleh et al., 2013).

Figure 2. Detailed process flowsheet for the storage mode of the proposed Methane-

Cycle shown in Figure 1a, adapted from Al-musleh et al. (2014a).

Figure 3. Detailed process flowsheet for methane purification and liquefaction part of the Methane-Cycle, adapted from Al-musleh et al. (2014a).

Figure 4. a) Hot and cold process composite curves for the storage mode of the MethaneCycle shown in Figure 2. The composite curves do not consider heat exchange below ambient temperature of $25^{\circ} \mathrm{C}$ (i.e. E-14 and E-15). b) Composite curves for the cryogenic heat exchangers E-14 and E-15 in the process shown in Figure 3. 
Figure 5. Process for storing gaseous methane at 205 bar and $31{ }^{\circ} \mathrm{C}$ during the storage mode of the Methane-Cycle, adapted from Al-musleh et al. (2014a).

\section{Table legends}

Table 1. Optimization parameters for the methane purification and liquefaction process shown in Figure 3.

Table 2. Key simulation results for the Methane-Cycle. Negative values indicate electrical power generation positive values indicate electrical power consumption.

Table 3. Basis of simulation of the storage mode of the cycle. 
(a) Storage mode

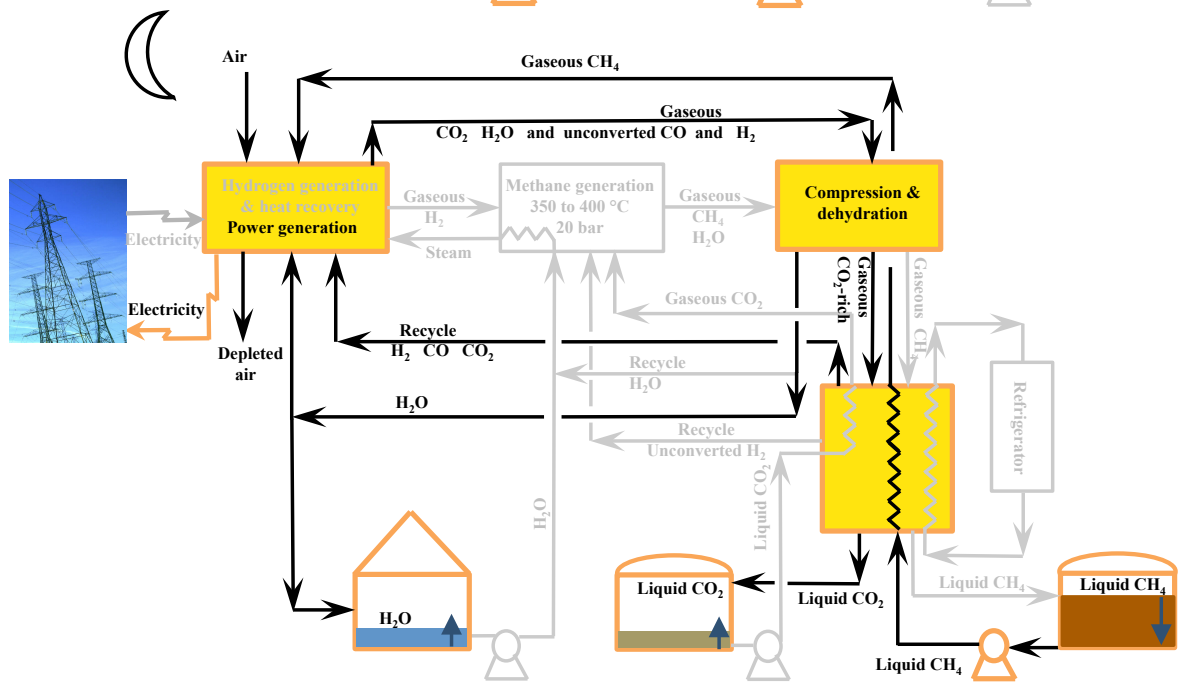

\section{(b) Delivery mode}

Renewable energy: Solar, wind, tidal waves, etc. $<$
Tank emptying $\checkmark$
Tank Filling

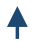

Active

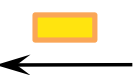

Inactive 
Figure 2

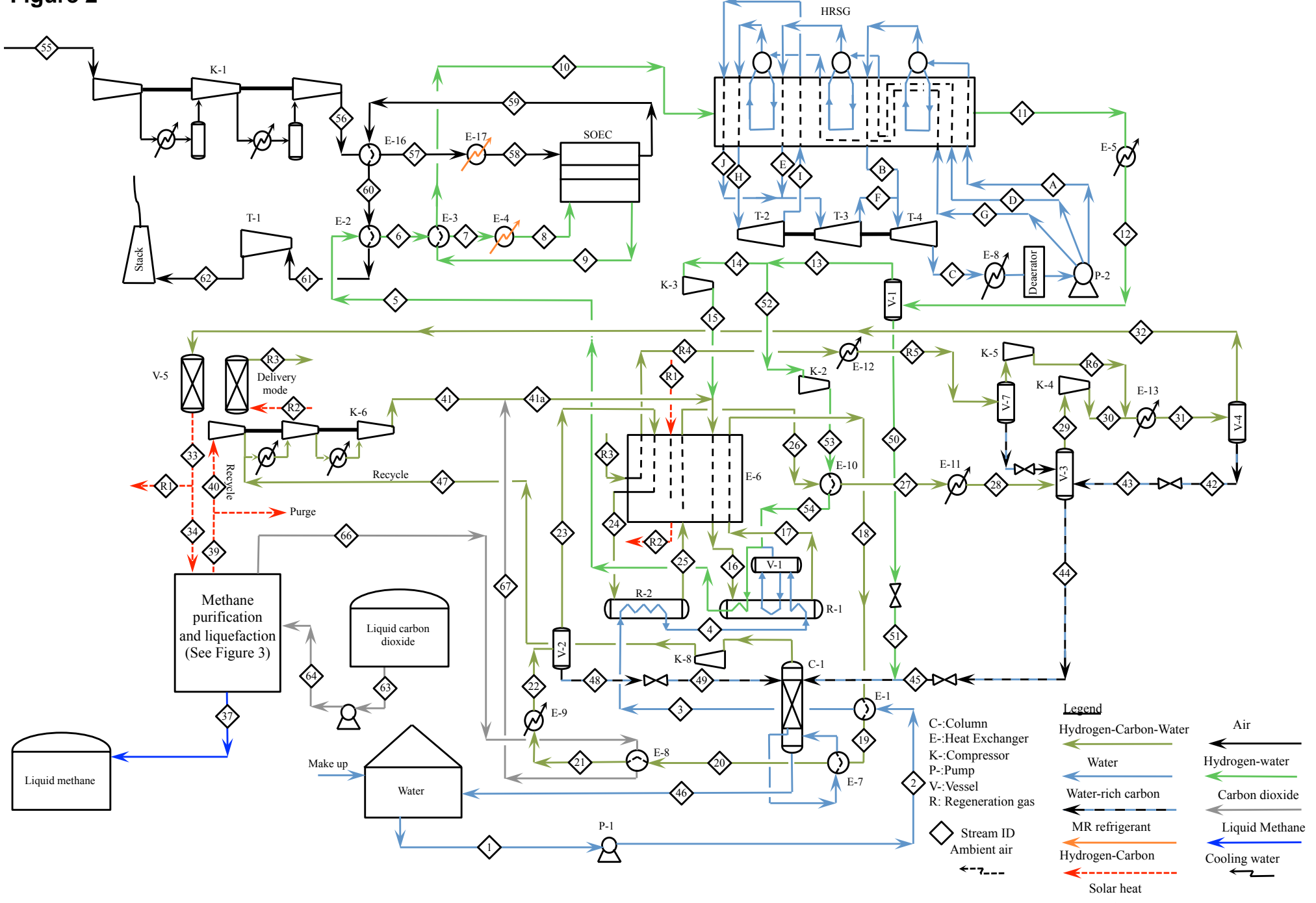




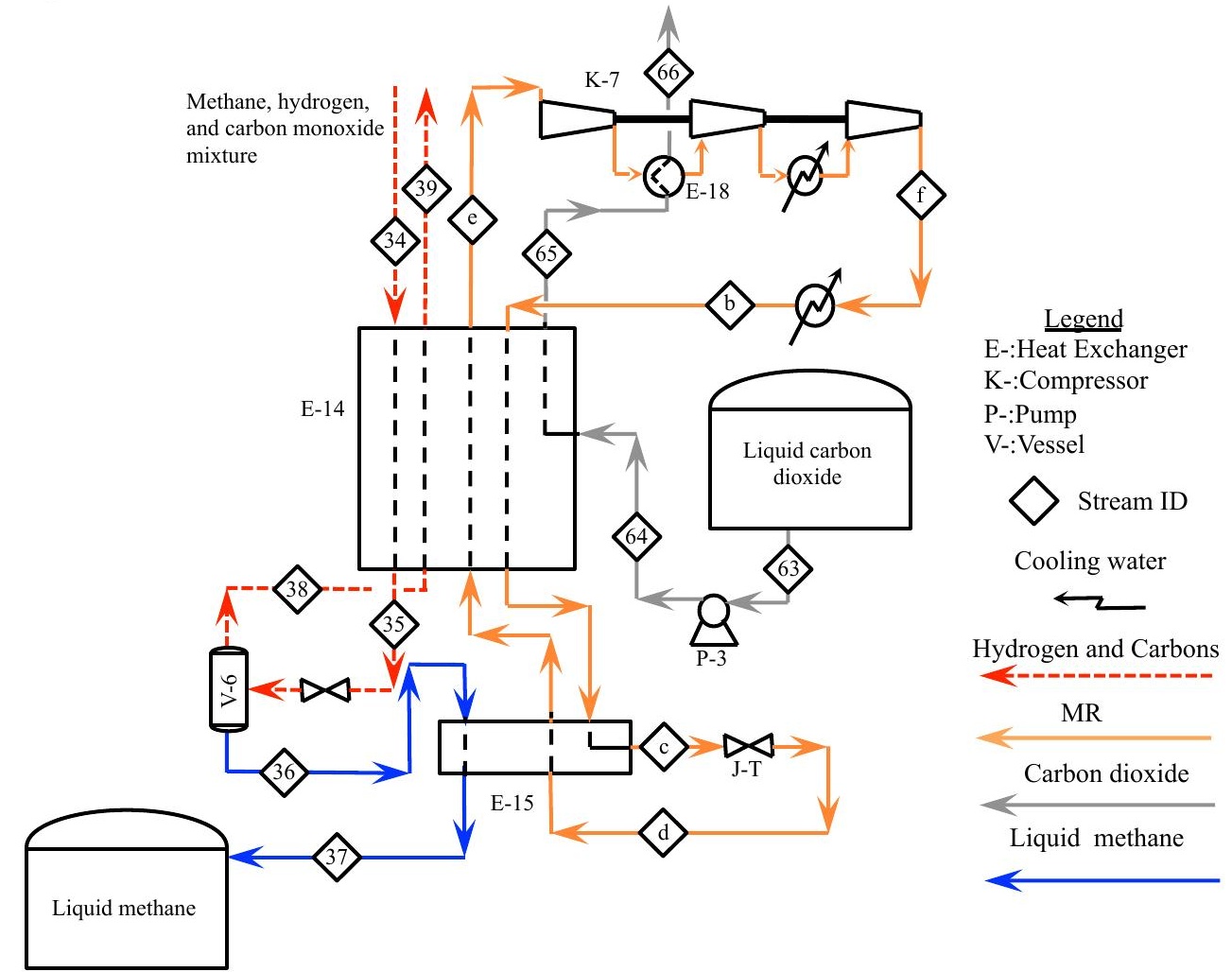



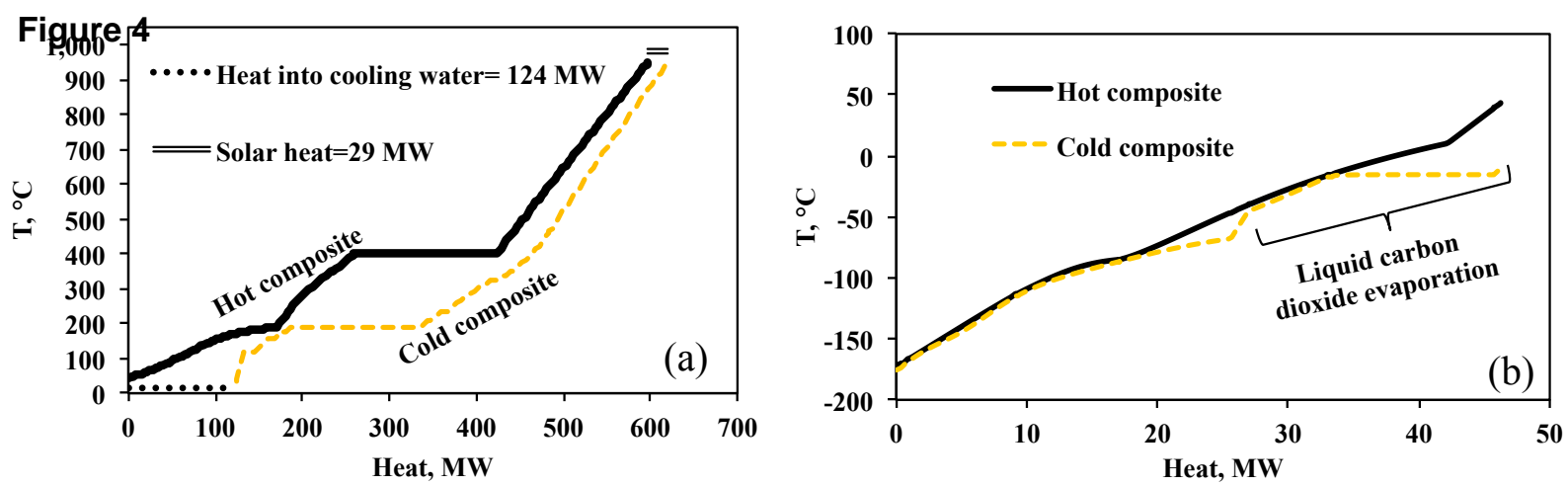

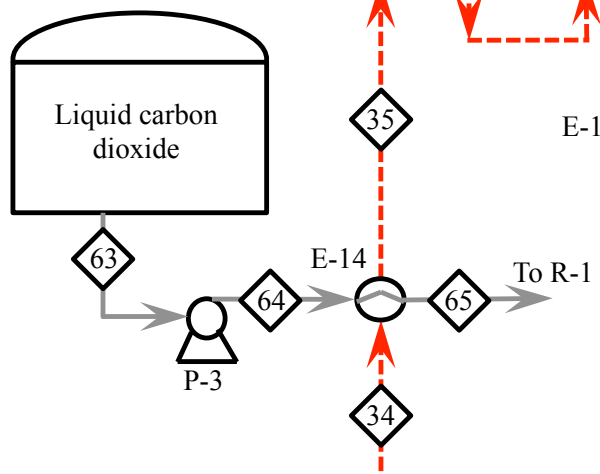

Methane, hydrogen, and carbon monoxide mixture from adsorber V-5
Legend

E-:Heat Exchanger

K-:Compressor

P-:Pump

V-:Vessel

$\circlearrowleft$ Stream ID

Cooling water

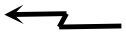

Hydrogen and Carbons

\section{Carbon dioxide

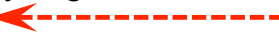

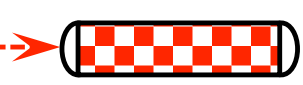


Table 1

\begin{tabular}{cc}
\hline Minimize & Compression power (K-7) \\
\hline Subject to & $\begin{array}{c}\text { E-14 and } 15 \text { minimum temperature } \\
\text { approach } \geq 1{ }^{\circ} \mathrm{C}\end{array}$ \\
\hline $\begin{array}{c}\text { Independent } \\
\text { variables }\end{array}$ & (1) Mixed Refrigerant composition in stream e \\
& $\circ$ Nitrogen $(0$ to 90 mole $\%)$ \\
& $\circ$ Methane $(0$ to 90 mole $\%)$ \\
& $\circ$ Ethane $(0$ to 90 mole $\%)$ \\
$\circ$ Propane $(0$ to 90 mole $\%)$ \\
\\
(2) MR flow in stream e $(1000$ to $5000 \mathrm{kmol} / \mathrm{h})$ \\
(3) K-7 discharge pressure $(5$ to 40 bar $)$ \\
(4) Stream c temperature $\left(-100\right.$ to $\left.-180{ }^{\circ} \mathrm{C}\right)$ \\
(5) Stream d pressure $(2$ to 30 bar $)$ \\
(6) K-4 discharge pressure $(20$ to 70 bar $)$
\end{tabular}


Table 2

\begin{tabular}{|c|c|c|c|}
\hline \multicolumn{4}{|c|}{ Methane-Cycle } \\
\hline \multirow{2}{*}{\multicolumn{4}{|c|}{$\begin{array}{c}\text { Storage mode } \\
\text { Methane }\end{array}$}} \\
\hline & & & \\
\hline \multicolumn{2}{|c|}{ Compressors power, MW } & \multicolumn{2}{|c|}{$\underline{\text { Heat exchangers }}$} \\
\hline $\mathrm{K}-1$ & 32.26 & \multicolumn{2}{|c|}{ Heat duty, MW } \\
\hline $\mathrm{K}-2$ & 0.63 & E-4 & 25.30 \\
\hline $\mathrm{K}-3$ & 16.01 & E-17 & 3.28 \\
\hline $\mathrm{K}-4$ & 3.82 & \multicolumn{2}{|c|}{ Exergy $^{2}, \mathrm{MW}$} \\
\hline $\mathrm{K}-5$ & 0.02 & E-4 & 19.27 \\
\hline $\mathrm{K}-6$ & 0.55 & E-17 & 2.50 \\
\hline $\mathrm{K}-7$ & 14.02 & \multicolumn{2}{|c|}{ Gross power ${ }^{3}, \mathrm{MW}$} \\
\hline $\mathrm{K}-8$ & 0.01 & \multicolumn{2}{|c|}{$1,081.46$} \\
\hline Turbines $p$ & MW & \multicolumn{2}{|c|}{ Net power ${ }^{1}, \mathrm{MW}$} \\
\hline $\mathrm{T}-1$ & -33.03 & \multicolumn{2}{|c|}{$1,032.80$} \\
\hline $\mathrm{T}-2$ & -2.59 & \multirow{2}{*}{\multicolumn{2}{|c|}{ Energy efficiency ${ }^{4}, \%$}} \\
\hline $\mathrm{T}-3$ & -4.59 & & \\
\hline \multirow[t]{4}{*}{$\mathrm{T}-4$} & -8.40 & \multicolumn{2}{|c|}{77.26} \\
\hline & & Delive & \\
\hline & & Liquid & \\
\hline & & $\begin{array}{l}\text { carbon dioxide } \\
\text { volume, } \mathrm{m}^{3}\end{array}$ & 718 \\
\hline \multirow{2}{*}{\multicolumn{2}{|c|}{ Pumps power, $\mathrm{kW}$}} & Net power & -141.67 \\
\hline & & output, MW & \\
\hline $\mathrm{P}-1$ & 99.60 & $\begin{array}{l}\text { Energy } \\
\text { Efficiency }, \%\end{array}$ & 71.01 \\
\hline $\mathrm{P}-2$ & 283.93 & \multicolumn{2}{|c|}{ Overall cycle } \\
\hline $\mathrm{P}-3$ & 72.45 & $\begin{array}{c}\text { Methane storage } \\
\text { volume, } \mathrm{m}^{3}\end{array}$ & 632 \\
\hline SOEC power, MW & 991.87 & $\begin{array}{c}\text { Storage } \\
\text { efficiency } 6, \%\end{array}$ & 54.86 \\
\hline
\end{tabular}

${ }^{1}$ Net power=Compressors power+ SOEC power + turbines power + pump power+ exergy of heat.

${ }^{2}$ Exergy of heat exchanger $=$ Heat duty $\times \frac{\text { Solar heat temperature-Ambiant temperature }}{\text { Solar heat temperature }}$ Solar heat temperature $=1,251 \mathrm{~K}$, Ambient temperature $=298 \mathrm{~K}$

${ }^{3}$ Gross power $=$ Compressors power+ SOEC power + pump power+ exergy of heat.

${ }^{4}$ Storage mode energy efficiency=Liquid methane LHV/net power input

${ }^{5}$ Delivery mode energy efficiency=net power output/Liquid methane LHV

${ }^{6}$ Storage efficiency $=$ Storage mode energy efficiency $\times$ Delivery mode energy efficienc 
Table 3.

\begin{tabular}{|c|c|c|}
\hline Description & Reference & Value/description \\
\hline Ambient conditions & Basis & $\begin{array}{c}1.013 \mathrm{bar}(1 \mathrm{~atm}) \\
25^{\circ} \mathrm{C} \\
50 \% \text { relative humidity }\end{array}$ \\
\hline $\begin{array}{l}\text { Cooling water supply } \\
\text { temperature }\end{array}$ & (Seider et al., 2009) & $32{ }^{\circ} \mathrm{C}$ \\
\hline $\begin{array}{l}\text { Expansion minimum } \\
\text { pressure }\end{array}$ & Assumption & $1.1 \mathrm{bar}$ \\
\hline $\begin{array}{l}\text { Heat exchangers maximum } \\
\text { pressure }\end{array}$ & (Heatric, 2012) & 100 bar \\
\hline $\begin{array}{l}\text { Heat exchangers maximum } \\
\text { temperature }\end{array}$ & $\begin{array}{c}\text { (Heatric, 2012; McDonald, } \\
\text { 1996) }\end{array}$ & $800^{\circ} \mathrm{C}$ \\
\hline $\begin{array}{l}\text { Heating above maximum } \\
\text { heat exchanger } \\
\text { temperature is carried out } \\
\text { using solar concentrators } \\
\text { with maximum temperature }\end{array}$ & Assumption & $1,000^{\circ} \mathrm{C}$ \\
\hline$\frac{\text { Pressure drops in heat }}{\text { exchangers }}$ & (Seider et al., 2009) & \\
\hline For boiling/condensation & & 0.10 bar \\
\hline For gases & & $0.21 \mathrm{bar}$ \\
\hline For low viscosity liquid & & 0.34 bar \\
\hline$\frac{\text { Heat exchangers minimum }}{\text { temperature approach }}$ & (Seider et al., 2009) & \\
\hline $\mathrm{T}<25^{\circ} \mathrm{C}$ & & $1{ }^{\circ} \mathrm{C}$ \\
\hline $\mathrm{T}=32.2$ to $148{ }^{\circ} \mathrm{C}$ & & $11.1^{\circ} \mathrm{C}$ \\
\hline $\mathrm{T}>148^{\circ} \mathrm{C}$ & & $27.8^{\circ} \mathrm{C}$ \\
\hline $\begin{array}{l}\text { Heat exchangers fractional } \\
\text { heat leakage }\end{array}$ & Assumption & 0 \\
\hline $\begin{array}{l}\text { Storage tanks heat leakage } \\
\text { SOFC/SOEC } \\
\text { (1) }\end{array}$ & Assumption & 0 \\
\hline $\begin{array}{l}\text { Maximum temperature } \\
\text { approach }\end{array}$ & (Lundberg et al., 2000) & $270{ }^{\circ} \mathrm{C}$ \\
\hline Maximum temperature & $\begin{array}{c}\text { (EG\&G TechnicalServices, } \\
\text { 2004) }\end{array}$ & $1,000^{\circ} \mathrm{C}$ \\
\hline DC to AC efficiency & (Adams \& Barton, 2010) & $96 \%$ \\
\hline Maximum pressure & (Lundberg et al., 2000) & $10 \mathrm{bar}$ \\
\hline Electrical current-SOFC & & $\begin{array}{l}\text { Sufficient to provide heat } \\
\text { for the steam reformer }\end{array}$ \\
\hline
\end{tabular}


Table 3 (continued)

\begin{tabular}{|c|c|c|}
\hline Description & Reference & Value/description \\
\hline Electrical current-SOEC & & At thermal neutral voltage \\
\hline Fuel reforming & $\begin{array}{c}\text { (Rostrup-Nielsen \& } \\
\text { Aasberg-Petersen, 2003) }\end{array}$ & $\begin{array}{l}\text { Steam reforming } \\
\text { integrated inside } \\
\text { the fuel cell }\end{array}$ \\
\hline $\begin{array}{l}\text { Oxygen concentration at } \\
\text { SOEC anode discharge }\end{array}$ & (McKellar et al., 2007) & 50 mole\% \\
\hline $\begin{array}{l}\text { Hydrogen concentration at } \\
\text { SOEC cathode inlet }\end{array}$ & $\begin{array}{l}\text { (McKellar et al., 2007; } \\
\text { Yildiz et al., 2005) }\end{array}$ & 10 mole\% \\
\hline $\begin{array}{c}\text { Phase separators pressure } \\
\text { drop }\end{array}$ & Assumption & 0.21 bar \\
\hline$\frac{\text { Number of compression }}{\underline{\text { stages }}}$ & (Seider et al., 2009) & \\
\hline Pout/ Pin & & Stages \\
\hline$<4$ & & 1 \\
\hline 4 to 16 & & 2 \\
\hline 16 to 64 & & 3 \\
\hline $\begin{array}{l}\text { Compressor discharge } \\
\text { maximum temperature }\end{array}$ & Assumption & $200^{\circ} \mathrm{C}$ \\
\hline $\begin{array}{l}\text { Gas turbines maximum inlet } \\
\text { temperature }\end{array}$ & $\begin{array}{l}\text { (Allam, Bolland, et al., } \\
\text { 2005) }\end{array}$ & $1,300{ }^{\circ} \mathrm{C}$ \\
\hline $\begin{array}{l}\text { Compressor isentropic } \\
\text { efficiency }\end{array}$ & (Hubbard, 2001) & $80 \%$ \\
\hline $\begin{array}{l}\text { Turbines isentropic } \\
\text { efficiency }\end{array}$ & (Foglietta, 2004) & $85 \%$ \\
\hline $\begin{array}{c}\text { Turbine electrical motor } \\
\text { Efficiency }\end{array}$ & Assumption & $97 \%$ \\
\hline $\begin{array}{l}\text { Adsorber maximum } \\
\text { pressure }\end{array}$ & $\begin{array}{l}\text { (Hydrocarbon Processing, } \\
\text { 2004) }\end{array}$ & 120 bar \\
\hline $\begin{array}{l}\text { Methane dehydration } \\
\text { molecular sieve }\end{array}$ & $\begin{array}{c}\text { (Hubbard, 2001; Maddox \& } \\
\text { Morgan, 1998) }\end{array}$ & $4 \mathrm{~A}$ \\
\hline $\begin{array}{l}\text { Carbon dioxide dehydration } \\
\text { molecular sieve }\end{array}$ & $\begin{array}{l}\text { (Hubbard, 2001; Maddox \& } \\
\text { Morgan, 1998) }\end{array}$ & $3 \mathrm{~A}$ \\
\hline $\begin{array}{l}\text { Sabatier reaction modeling } \\
\text { approach }\end{array}$ & (Brooks et al., 2007) & Equilibrium \\
\hline $\begin{array}{l}\text { Cryogenic refrigeration for } \\
\text { storage mode of Methane- } \\
\text { Cycle }\end{array}$ & (Al-musleh, 2010) & Mixed Refrigerant (MR) \\
\hline
\end{tabular}


Table 3 (continued)

\begin{tabular}{|c|c|c|}
\hline Description & Reference & Value/description \\
\hline \multicolumn{3}{|l|}{ Thermodynamic modeling } \\
\hline Mixtures & (Horstmann et al., 2005) & $\begin{array}{c}\text { Predictive Soave-Redlich- } \\
\text { Kwong (PSRK) }\end{array}$ \\
\hline Pure water & (Aspen Technology, 2006) & NBS/NRC steam tables. \\
\hline \multicolumn{3}{|l|}{$\frac{\text { Heat Recovery Steam }}{\text { Generator (HRSG) }}$} \\
\hline Water contamination & Assumption & Pure water \\
\hline Maximum steam pressure & (Allam, White, et al., 2005) & 128 bar \\
\hline $\begin{array}{l}\text { Maximum steam turbine } \\
\text { temperature }\end{array}$ & (Allam, White, et al., 2005) & $518^{\circ} \mathrm{C}$ \\
\hline $\begin{array}{l}\text { Minimum steam turbine } \\
\text { outlet pressure }\end{array}$ & (Smith, 2005) & 0.07 bar \\
\hline $\begin{array}{l}\text { Minimum steam turbine } \\
\text { inlet pressure }\end{array}$ & (Woodruff et al., 2012) & 5 bar \\
\hline $\begin{array}{l}\text { Steam turbine discharge } \\
\text { moisture content }\end{array}$ & (Woodruff et al., 2012) & 10 to $15 \%$ \\
\hline $\begin{array}{c}\text { Number of steam pressure } \\
\text { stages }\end{array}$ & Assumption & 3 \\
\hline Number of reheats & Assumption & 1 \\
\hline$\underline{\text { Purge percentage }}$ & Assumption & $1 \%$ \\
\hline Storage mode & & $1 \%$ \\
\hline Delivery mode & & $1 \%$ \\
\hline $\begin{array}{l}\text { Day time sun availability in } \\
24 \text { hours }\end{array}$ & Assumption & $4.8 \mathrm{~h}$ \\
\hline $\begin{array}{l}\text { Minimum temperature for } \\
\text { carbon dioxide rich streams }\end{array}$ & Avoid freezing & $-55^{\circ} \mathrm{C}$ \\
\hline $\begin{array}{l}\text { Minimum pressure for } \\
\text { carbon dioxide rich streams }\end{array}$ & Avoid freezing & 9 bar \\
\hline $\begin{array}{l}\text { Liquid carbon dioxide } \\
\text { purity }\end{array}$ & Assumption & $>99$ mole $\%$ \\
\hline
\end{tabular}

